分科会報告 No. 315

\section{すベり朝受の動特性とその応用に関する 研究分科会報告*}

本分科会はすぺり軸受で支えられた回枟軸の振動を 抑制する上で鼠も重要なすべり軸受の動特性に関し て，乙の計算法，测定法，計算結果，測定結果，お上 び動特性の㚇用例について調查研究を行うとともに, すぺり軸受特性データの收集を行ってきた。その結果 “すへりり軸受の勳特性と回転機械の振動一最新資料に 菜づく設計一の応用”之題する講習会を機械力学委貣 会企画のもとで实行し，また『すべり軸受特性データ 集』をとりまとめた。

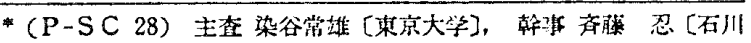

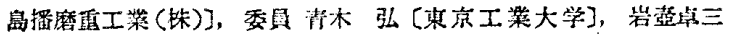

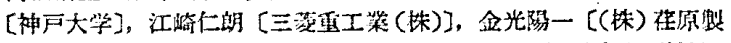

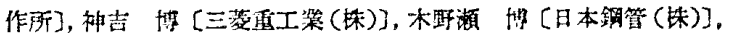

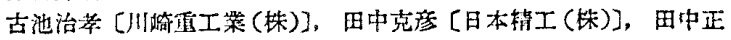

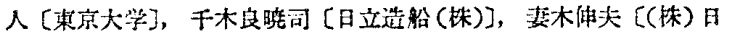

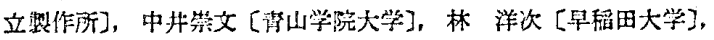

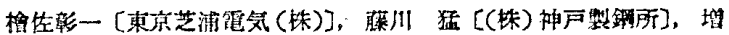

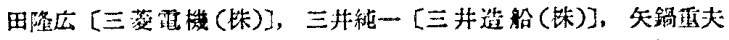

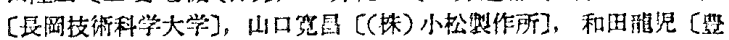
田工機 (怢)]
}

成果都告其では下記の慗項について述へててる。(1) すべり軸受の動特性が重要視されるにいたった捱火的

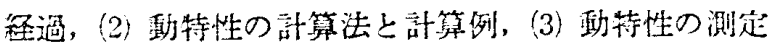

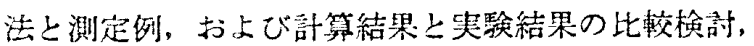

（4）楿受特性データ集の概略上使用法, データ集を用 いた程験およで閏題点.

回転軸の振動と油膜の㲜特性に関して：(5) 自励振 動, (6) 不つりあい掓動，(7) 外部励振に上るロ一タの 振動。

実践への芯用例として：(8) 菽文タービン発電機, (9) ポンプ。(10) ターボ圧繀機.

すベり軸受研究の動向として：(U) すべり軸受の研 究一現状と将来.

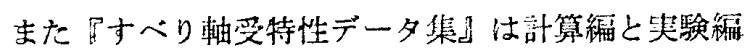
からなり，部算編では合郭 59 種類の軸受特性データ (シ゚ンマーフェルド数に対する偏心率, 偏心角, 摩摖 係数，流量，ばね係数，および減表係数)，特別検討 李項 (境界条件, 蝠径比, 乱流, および粘度変化)， および安定限界線図を収録し，㕵駼編では合尌 11 種 類の軸受特性值を收䟿している。

以上述べたように，すべり軸受で支えられた回枟軸 の振勀を抑制する上で重要な問題点を明らかにすると ともに，現時点で最も雃富な軸受特性データを提供し ている。

(文珼 染谷 常雄)
分科会報告 No. 316

\section{機械・構造物の複合原因による事故と その防止対策法調查分科会報告*}

本分科会は機械や模造物などに発生した破壊事故例 調䄳・分析して，類似小事故の再発防止対策法を破

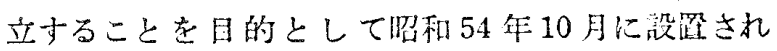

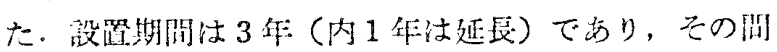
に29回の分科会が開倠された。各会㼁ごとでは, 委

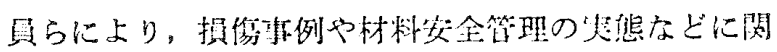
ナる1〜2件の話題提供があり，それに刘して活発な 赭踚が行うれた。

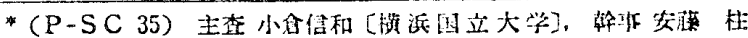

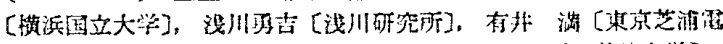
気 (抹)], 井上成恭 [埼玉工栄大学]，大内田 久[工举院大学]。

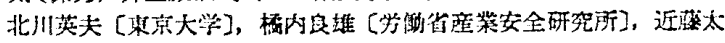

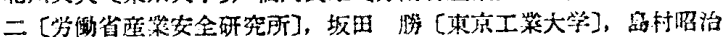

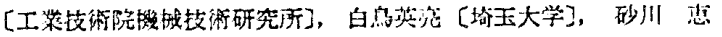
[来京大学]，津村利光 [神系川大学]，中野知敬 [東洋エンジニフ

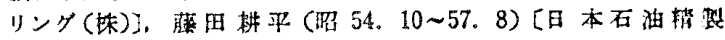

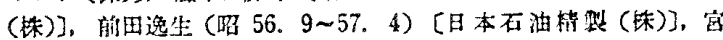

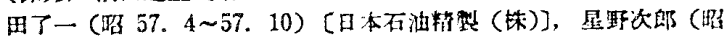

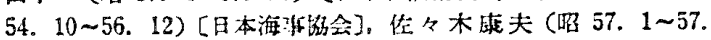

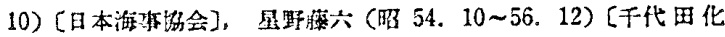

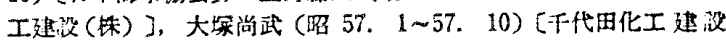

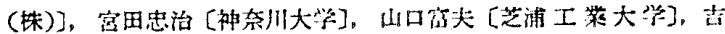

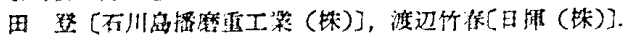

本乹告舅はそれらの話題および討墖に基ういて作成 きれたものであり，その内容は大略次のとおりである.

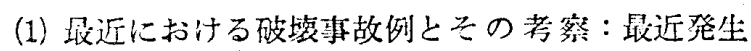
した在力容器, 貯槽, 配管などの損伤本例を調查分析。

（2）腐食から災霄への動態：腐全を原因とする可故が

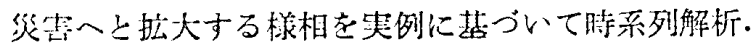

(3) 円䉍形大形タンクの問題点: 大形タンクアニュー ラ板の忉啠迩定法. (4) 航空機模造の文全性: 航空機

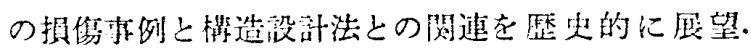

(5) 化学プラントにおける鋼權造物のぜい化上問題点：

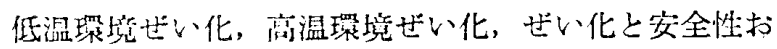

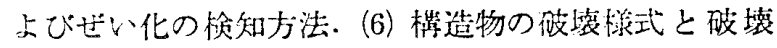

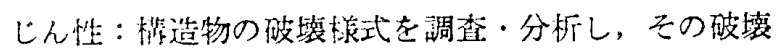
柍式を模擬した破壊じん性試験法を提案.（7）フラク トグラフィによる定显的破壊解析手法. (8) 鋼の溶融 金属によるぜい化について（9）石油精製におけるト ラプルとその対籍. (10) 加熱炉マニホルドの損倠. (11) 队柱䈷造にお打る婊面き裂。

以上の上うに，本棋告䡒は機械・满造物の破壊解析 や本故防止対策についてまとめたものであり，関係各 位に法有益な资料となり得るものと考えられる。

(支責 小合 倍和) 